\title{
Potential of Green Construction in Malaysia: Industrialised Building System (IBS) vs Traditional Construction Method
}

\author{
M.A.O Mydin ${ }^{1}$, A.F. Phius ${ }^{2}$, N. Md Sani ${ }^{3}$, N.M. Tawil ${ }^{4}$ \\ ${ }^{1,2,3}$ School of Housing, Building and Planning, Universiti Sains Malaysia, 11800 Penang, Malaysia \\ ${ }^{4}$ Department of Architecture, Faculty of Engineering \& Built Environment, Universiti Kebangsaan \\ Malaysia, Bangi 43600, Malaysia
}

\begin{abstract}
This study is conducted to compare between the two approaches of construction. It is carried out through case studies on construction sites, distribution of a total of 100 questionnaires as well as interviewing respondents who are related to this discourse. The case studies for this research were carried out at four construction sites within the Malaysian state of Penang. Two case studies used Industrialised Building System method while the remaining two deployed the traditional method of construction. Based on the analysis of obtained results, it can be surmised that the Industrialised Building System approach has more to offer compared to the traditional method. Among these advantages are; reduced construction durations, reduced overall cost, reduced labour requirements, better site conditions and the production of components of higher quality among others. This study also managed to determine the perceptions of key players in the industry and their rationales in preferring the traditional approach while at the same time, admitting to the edges offered by the Industrialised Building System.
\end{abstract}

\section{Introduction}

The construction industry in Malaysia is experiencing a transformation from conventional methods to a more systematic and mechanized method known as the Industrialised Building System (IBS). Each state in Malaysia is currently examining the developments of the IBS and its potential to overcome the shortages of housing accommodations in this country [1]. The Malaysian government, involved through its agency, the Construction Industry Development Board (CIDB) has been persistently pushing the construction industry to utilize of the Industrialised Building System (IBS) method of construction since the year 2003 [1]. It is a part of an incorporated endeavor to further improve the aptitude, potential, effectiveness and competitiveness of the industry as well as to diminish the industry's dependence on foreign labours [2]. This is also an attempt in the Malaysian construction industry to encourage positive inroads in matters related to construction-site safety with regards to a working environment which is cleaner, more convenient and more organized [3]. This production is also mentioned as being able to provide more protection to the environment as it secures the sustainability of the industry [4].

The IBS proved to be a success. Not only it was efficient in accelerating the construction of housing projects, but it also improved the quality and affordability of the projects in which the IBS was deployed [5]. Based on different reference materials accepted by authorities in the construction fraternity, we have several ways of defining the IBS [6]. Despite the IBS being well-known and accepted by most construction firms due to its theoretical advantage in terms of speed, safety and 
quality, wet construction method is still widely regarded in Malaysia as a conventional and safe option regardless of incurring higher costs and slower production rates [7].

Traditional construction is one of the earliest approaches practiced in the construction industry. It involves procedures where everything is done at the project site without prior preparation of construction materials at manufacturing plants [8]. This type of construction is appropriate for countries that have limited skilled labour, lack of heavy machineries and a shortage of relevant technology. This system is applicable to almost all types of buildings. It involves a formwork which is used as a mould. Concrete slurry is poured into this temporary system that also acts as a temporary support for the structures [9].

The conventional building system had predominantly been built using reinforced concrete frames and it is typically divided into two major components. The first component is the structural system which includes cast in-situ columns, beams, slabs and frames [10]. These frames are constructed through four successive operations which are the erection of timber formworks and scaffoldings, the erection of steel bars, the pouring of fresh concrete into forms and finally, the dismantling of formwork and scaffoldings [10]. These operations are labour intensive, tedious and require a lot of onsite coordination. The second component consists of bricks and plaster as the non-structural infill material $[11,12]$. It involves high costs for construction taking into account the expenditures for labour, raw materials, transportation as well as the required lengthy construction periods.

The increasing demands of clients in the construction industry have led to the selection of a faster and cheaper construction method which, by the way, is capable of producing higher quality results. For that reason, builders involved in the construction sector are required to decide either to utilize the IBS or the traditional method of construction. This study will highlight all the differences between these two construction methods. Widespread knowledge and a good understanding of the Malaysian construction industry will also be fostered.

\section{Result, Analysis and Discussion}

The case study in this research was conducted to identify the strengths and weaknesses of the Industrialised Building System as well as those of the traditional method deployed in the construction of four targeted projects around Penang. The four sites are Kompleks Ibu Pejabat Mahkamah Syariah, Pulau Pinang (IBS), Sekolah Kebangsaan Minden Height, Gelugor, Pulau Pinang (IBS), Masjid Jamek Sg. Gelugor, Pulau Pinang (Traditional Method) and 11 Unit Rumah, Tingkat Dua, Tingkat Satu, Tingkat Basemen, George Town, Pulau Pinang (Traditional Method)

\subsection{Respondent Backgrounds and General Information}

In this study, 100 respondents were involved. The biggest representation in this study is from contractor companies (53\%), followed by developer companies (17\%), the Public Works Department $(15 \%)$, consultation firms $(8 \%)$ and the smallest percentage is contributed by architecture firms (7\%). According to survey forms which were distributed to builders, majority of them had working experiences of between 6 and 9 years. Generally, those with more than 6 years working experiences are familiar with construction sites and have sufficient experience and knowledge in both of these methods.

\subsection{Knowledge and Application of the Industrialised Building System}

As reflected by the diagram in Fig. 1, 90\% of the respondents were familiar with the IBS but rarely applied this method in construction. The IBS is rarely performed because of the small numbers of contractors who refuse to manage projects involving the implementation of the IBS method. Furthermore, they were more familiar with the traditional construction method and they might have found it difficult to embrace a new approach to construction. In addition, the financial factor is another 
reason they dared not involve themselves in the construction of IBS projects. The lack of knowledge in the IBS had discouraged builders from participating in the constructions of IBS projects. Although only $10 \%$ of the respondents were familiar and regularly deployed the IBS method, this trend might change over the next few decades.

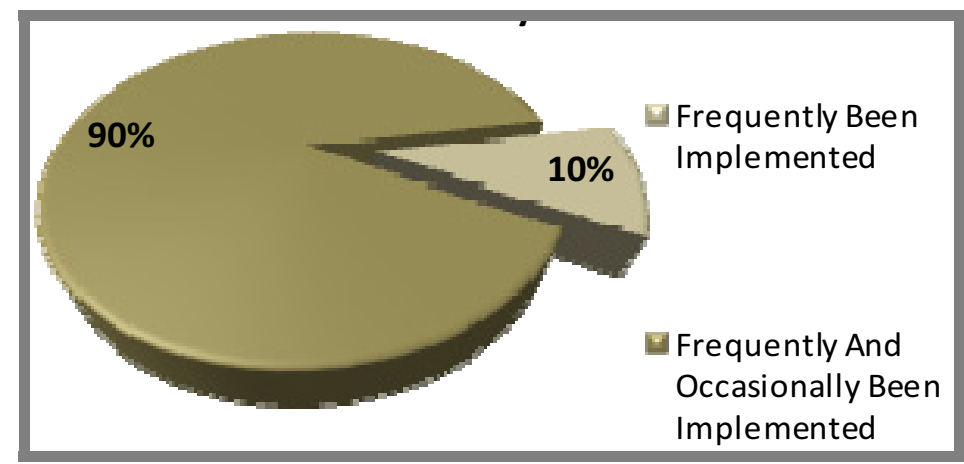

Figure 1: Familiarity of Industrialised Building System in Malaysia

There are various mediums through which the Industrialised Building System had obtained itself attention from among individuals in the construction industry here in Malaysia. Many builders are introduced to the use of the pre-cast construction method through workshops, seminars and courses. Government agencies such as the Public Works Department (PWD) and the Construction Industry Development Board (CIDB) have played their roles in providing a variety of information to the players in the construction industry. Other means are through friends and associates in the construction industry, from the Internet and from other electronic media. The least popular information channels are newspapers, articles and etc.

According to data analysis, the majority of respondents at $72 \%$ admitted having sound knowledge on the IBS while $1 \%$ declared that they are in the possession of excellent knowledge on this matter. The remaining $27 \%$ of the respondents who participated in the questionnaire admitted that they are rather poor when it comes to knowing details regarding the construction method involving the IBS approach. This could be a result of their recent entry into the construction industry.

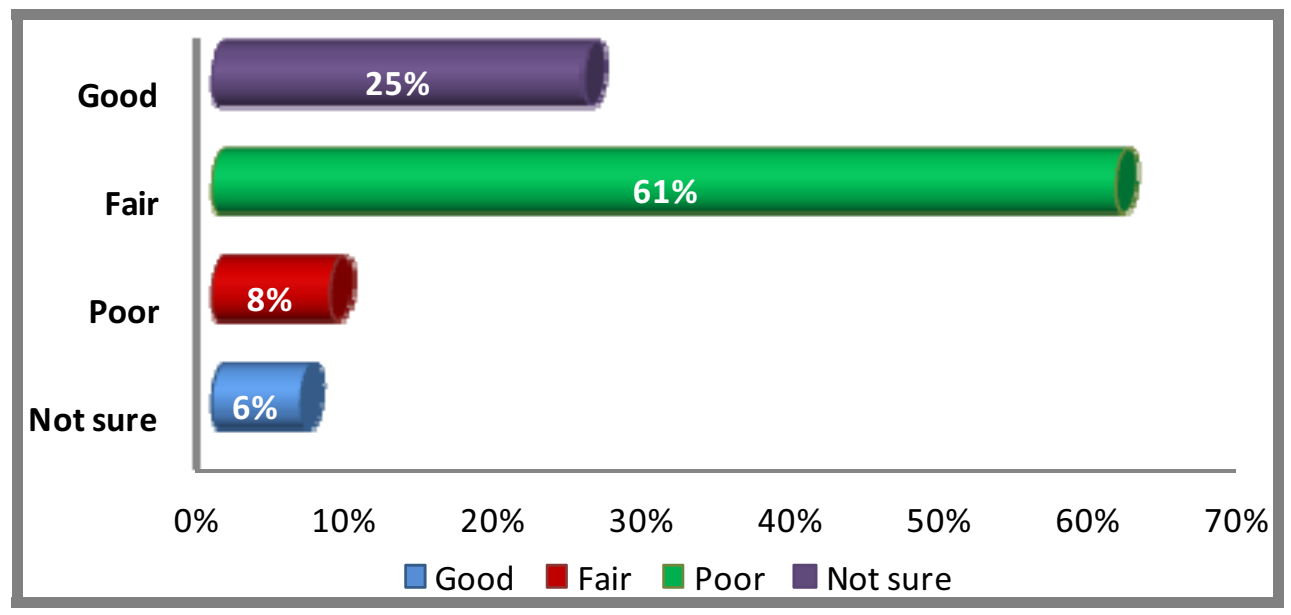

Figure 2: Level of Development of the IBS in Malaysia

With reference to Fig. 2, 61\% of the builders agreed that the development of the IBS in Malaysiais moderate while $8 \%$ of the respondents stated that the level of IBS implementation in 
Malaysia is very low. $6 \%$ were unsure about the developments of the IBS in Malaysia. Nonetheless, $25 \%$ of the respondents agreed that the development of the IBS in Malaysia is at an encouraging level. This is due to the various initiatives taken by the government to implement construction projects with the IBS concept especially in government projects.

\section{Strengths and Weaknesses of IBS and the Traditional System}

This study was conducted through case studies, questionnaires and interviews. Respondents involved are builders from the four construction sites around Penang which had been visited.

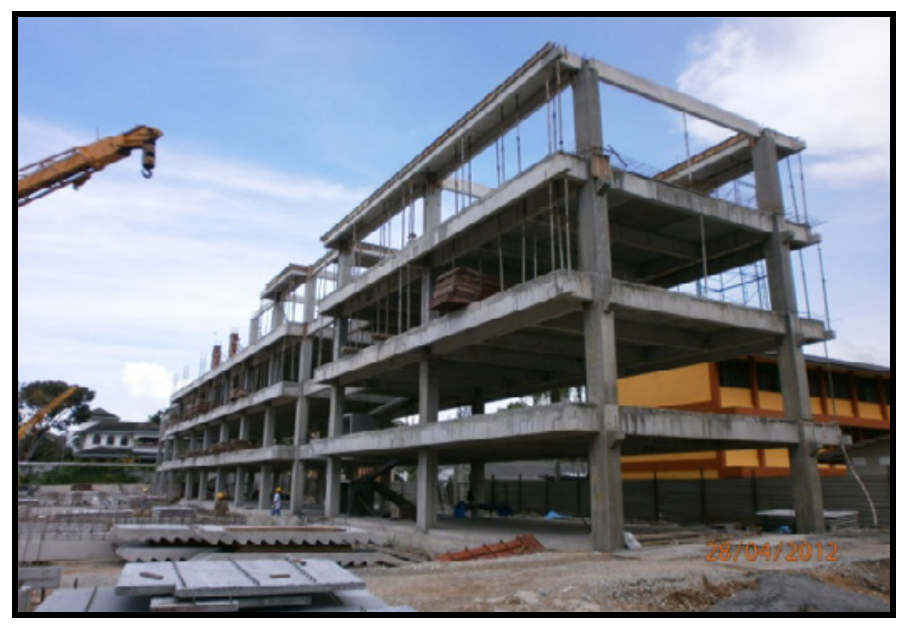

Figure 3: Erection of IBS Structure Component at Sekolah Kebangsaan Minden Heights

These case studies were conducted to identify the strengths and weaknesses of the Industrialised Building System and the traditional method for the four projects in Penang. Among these are Kompleks Ibu Pejabat Mahkamah Syariah, Sekolah Kebangsaan Minden Heights, Masjid Jamek Sg. Gelugor and also the SP Setia housing project specifically 11 Unit Rumah, Dua Tingkat Satu Tingkat Basemen. Many researchers have tried to compare these two methods of construction.

The results from the case studies indicate that the IBS has significant advantages over the conventional method of construction. Fig. 3 show the erection of structure at Sekolah Kebangsaan Minden Heights which was completed within 3 months. Responses from the interviews conducted upon relevant respondents from each of the four projects also point in the same direction. For example, in the project involving the school building of Sekolah Kebangsaan Minden Heights, it took less than three months to erect the structure of the building as a whole while in the case of Masjid Jamek at Gelugor, a duration of four to five months was required to complete the building structure. This indicates that the IBS approach to construction can cut down on the overall construction period. Statistically, IBS construction projects can save up to $30 \%$ of time compared to the conventional method [13].

Analysis from the questionnaires indicates a total mean score of 3.45 was obtained. The score signify that $50 \%$ of the respondents agreed that constructions can be completed rapidly because of the earlier manufacturing and assembling of pre-cast components in factories. In contrast, projects that deploy the traditional method are difficult to complete within a short period of time. This method requires a long duration before completion since moulds need to be built and the concrete has to be given enough time to set and so on. 


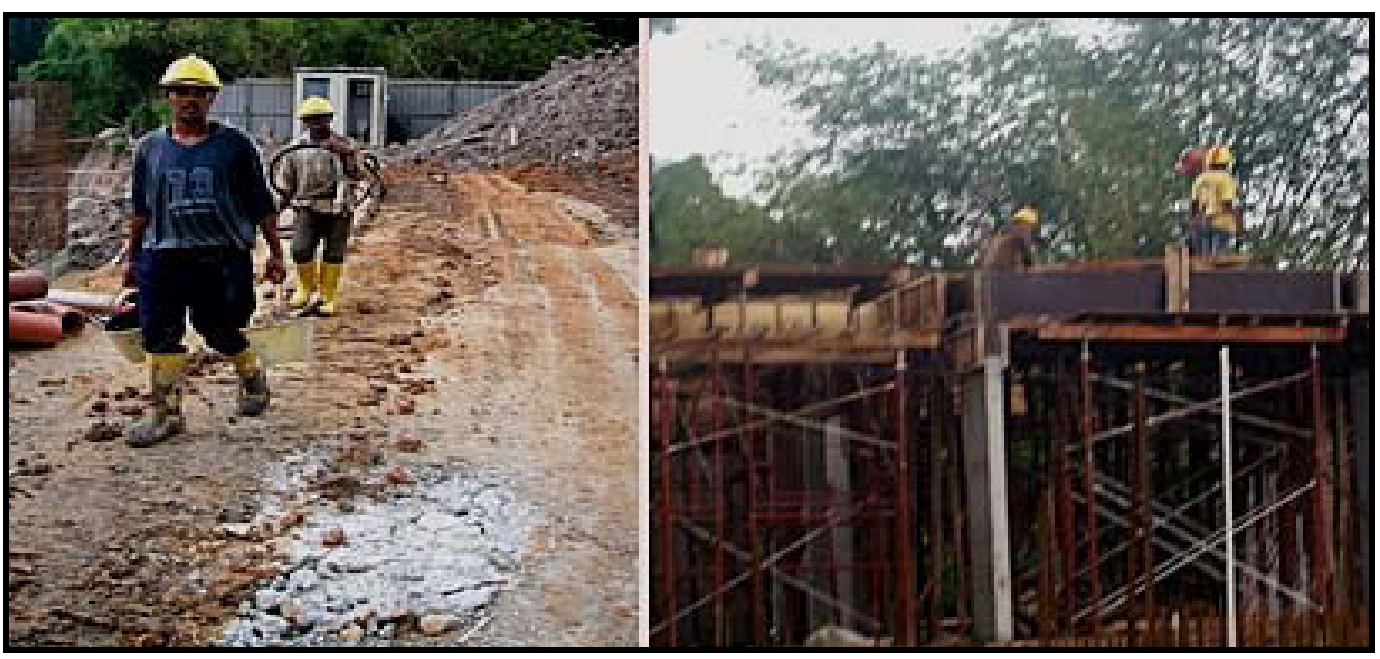

Figure 4: Labours at SP Setia site (traditional construction)

Through the case studies, significant differences in terms of the workforce utilization can be observed. In fact, one would be able to discern whether a project was deploying the IBS or the traditional approach by casting a single glance at the construction site during working hours. Construction is a labour-intensive industry, especially in conventional construction. With an overall mean score of 3.10, the IBS application is able to reduce labour at the construction sites. Pre-cast construction method (IBS) is a relatively less labour-intensive method, but it still requires skilled labours to perform on-site work such as the installation of IBS components. This explains the minimal number of labours because they are only engaged for the installation of the IBS components [14]. Contrary to conventional methods which require more labour to complete work such as formwork fabrications, reinforcement bar or steel cage fabrications, formwork installations, reinforcement bar installations, concrete placements and formwork dismantling; the use of the IBS method will reduce the dependency on foreign labour. However, the use of skilled labour is needed for the installation of mechanical equipments and components that involves heavy machineries like cranes at construction sites. Fig. 4 shows, traditional construction methods had involved more construction workers on the construction site.

Through research, labour efficiency is one of the factors that contribute to the increased in productivity. It is an important element in projects that will determine the amount of building costs [15]. Reduction in labour productivity can affect cost of labour. Workers who do not produce work optimally at the construction site will impede the progress of the project and lengthen its completion. This phenomena makes the conventional method appear cheaper compared to the IBS approach.

Besides, the IBS offers lower cost to build large and repetitive designs within a short period of time. This leads to the lowering of the overall cost of the project provided that the project is a large one which involves high degrees of repetition. However, the cost of the initial stages of construction are usually higher because during these phases, the involvement of complex machineries would be eminent for the preparation, casting, curing and treatment, stripping and demoulding as well as in the inspection, lifting and handling processes. Furthermore, IBS components are also considered to be expensive due to the small numbers of IBS components manufacturers in Malaysia.

The IBS initiates less labour during construction. Besides, it is also able to eliminate the use of conventional formworks which leads to waste production and excessive costs in construction. This helps to reduce overall costs in the construction of IBS projects as compared to projects using the traditional method which usually incur high costs partially due to concrete wastage. Construction process will take a longer time to complete and it would produce more wastage in construction materials [16]. 
Through the case studies of the four construction projects which were respectively based on the IBS and the traditional method, it can be concluded that those two construction methods are affected by the way the construction sites were managed by the contractors and the labours. However, new moulds will be required unless the project manager decides to practice a monotonous approach and repeat the designs over and over again. In the event that new moulds are conscripted, the charges incurred will be expensive [17]. This is very much in contrast to the traditional method which offers a variety of designs and more than half of the respondents agree with this due to the fact that the production of desired designs using the traditional method is easy to attain. The respondents recorded a mean of 2.84 to indicate that the components involved in the traditional building method are easily assembled.

\section{Perception Levels of Local Builders toward the IBS and Traditional System}

The traditional method is much more preferred by the respondents. Builders are more likely to prefer this method because they have grown familiar to this approach. In addition, they are also reluctant to change to new methods such as the IBS because they might have insufficient knowledge on this method. However, they do not deny the advantages of the IBS approach [18].

The respondents agreed that the IBS method can shorten the construction time compared to the traditional method. The IBS approach can consume less construction time because it doesn't required the erection of formwork, concrete castings, and concrete curing and so forth. The components only need be erected on site, and not constructed, because they have already been completely produced at the factories. This kind of situation allow for the construction time of IBS to be faster than that of the conventional method. In fact, in terms of construction costs, the IBS is able to reduce the overall construction cost by $0-20 \%$. This is because, as a whole, IBS constructions will be able to save in terms of waste materials as well as on the minimizing the labours amount at the construction sites.

It is also proven through the case studies and interviews that the IBS construction is capable of saving on labour because it only requires skilled workers to set up the components at the construction sites and workers to control the operation of the machineries at the beginning of the manufacturing and also during the installation of components.

\section{Conclusion}

Various efforts were concerted with the aim of fulfilling all of the pre-determined research objectives pertaining to the two approaches of building construction in Malaysia. The first objective in this study is to identify the strengths and weaknesses of these two building systems. This is fulfilled by conducting case studies on project sites, acquiring data from questionnaires and interviewing respondents at the project sites. Besides from an in-depth literature review, relevant information was also derived from catalogues issued by the CIDB which contained sufficient data related to this discourse. The IBS building construction approach is capable of hastening project completion, increasing quality and site security as well as minimizing the number of site workers.

The second objective of this study is to gauge the perception levels regarding the IBS and the traditional method approaches among local builders. This is so that the builders' preferences can be noted as well as their opinions regarding the factors that they considered before coming up with their choices. This objective was attained through means of a questionnaire and a round of interviews. Approximately half of the respondents are reluctant to switch to the IBS and prefer the old conventional method. This could be due to the nature of humans which resist changes after achieving a comfortable pedestal, one which they have grown accustomed to. It is important to note however that they do not reject the notion that the IBS brings with it a host of advantages. 


\section{References}

1. CIDB, 2005. IBS Survey 2005. Survey on Malaysian Architects' Experience in IBS Construction. K. Lumpur

2. CIDB, 2003a. Industrialised Building System (IBS) Roadmap 2003-2010. K. Lumpur.

3. Mirsaeedie, L., 2003. Application of Industrialized Building Systems (IBS) in Rural Settlements Towards Sustainability, World Applied Sciences Journal, 16 (5): 729-733

4. Hassim, S., S. Jaafar and A.Z. Sazalli, 2009. The Contractor Perception Towers Industrialised Building System Risk in Construction Projects in Malaysia. American J. Appl. Sci., 6 (5): 937942.

5. Othuman Mydin, M.A., Y.C. Wang, 2011. Elevated-Temperature Thermal Properties of Lightweight Foamed Concrete. Journal of Construction \& Building Materials, 25 (2): 705-716

6. CIDB, 2005. IBS Survey 2005: Survey on Malaysian Architects' Experience in IBS Construction. Kuala Lumpur.

7. CIDB, 2003a. Industrialised Building System (IBS) Roadmap 2003-2010. Kuala Lumpur.

8. Othuman Mydin, M.A., 2011. Thin-walled steel enclosed lightweight foamcrete: A novel approach to fabricate sandwich composite. Australian Journal of Basic and Applied Sciences, 5 (12): $1727-1733$

9. Dacjuk, T.A., V.F. Vasil'ev, V.V. Derugin, U.P. Ivlev, 2005. New technology for designing microclimate support systems in buildings. Bulletin of Civil Engineers, 3 (4): 53-57

10. M.A. Othuman Mydin, N. Md Sani, M. Taib, 2014. Industrialised Building System in Malaysia: A Review. MATEC Web of Conferences, 10: 01002, DOI: http://dx.doi.org/10.1051/matecconf/20141001002

11. Othuman Mydin, M.A., Y.C. Wang, 2011. Structural Performance of Lightweight Steel-Foamed Concrete-Steel Composite Walling System under Compression. Journal of Thin-walled Structures, 49 (1): 66-76

12. M.A. Othuman Mydin, N. Md Sani, A.F. Phius, 2014. Investigation of Industrialised Building System Performance in Comparison to Conventional Construction Method. MATEC Web of Conferences, 10: 04001, DOI: http://dx.doi.org/10.1051/matecconf/20141004001

13. Norgaard, J., M.A. Othuman Mydin, 2013. Drywall Thermal Properties Exposed to High Temperatures and Fire Condition. Jurnal Teknologi, 62 (1): 63-68

14. Badir, Y.F., M. Abdul Kadir and A.H. Hashim, 2002. Industrialized Building Systems Construction in Malaysia. Journal of Architectural Engineering, pp: 19-23

15. Othuman Mydin, M.A., Y.C. Wang, 2012. Mechanical properties of foamed concrete exposed to high temperatures. Journal of Construction and Building Materials, 26 (1): 638-654

16. Abas A., M.H. Hanafi, F.A. Ibrahim, 2013. Competencies Factors of Malaysian Architectural Firms Towards the Implementation of Industrialized Building System, Middle-East Journal of Scientific Research 18 (8): 1048-1054.

17. Onyeizu, E.N., Abu Bakar, A.H., 2011. The Utilisation of Industrialised Building System in Design Innovation in Construction Industry, World Applied Sciences Journal, 15 (2): 205-213

18. S.W. Tan, M.A. Othuman Mydin, N. Md Sani and M.Z. Sulieman, 2014. Investigation into Common Decay of Educational Buildings in Malaysia. MATEC Web of Conferences, 10: 05001, DOI: http://dx.doi.org/10.1051/matecconf/20141005001 